\title{
Creating Shared Value with Consumers
}

Who are companies for? Are they just for one group of people, such as shareholders, or do they earn their legitimacy by serving many different groups of people at the same time?

In this issue of International Commerce Review, Nestlé CEO Paul Bulke provides one clear perspective. The foundations of sustainable success lie in creating shared value - and the trick is knowing how to do so in an integrated, systemic way. Thus, Nestlé food products don't only aim to taste good, they also seek to deliver health and wellness. The process of making them provides jobs and, if organized properly, environmentally sustainable economic development. And if this is done well, the net result is consistent delivery of shareholder value too. Understanding value chains in these terms has far-reaching implications for the whole industry.

Alex Cheatle, CEO of Ten Group, presents a very different perspective on building shared trust with consumers. Ten is driven by its customers literally. It doesn't have anything to 'sell' to them. It simply acts on their instructions, doing what they ask it to do. This highly innovative business model works because of two things. First, by acting only on members' instructions, Ten gains unique insights into what they really want. Second, their wants and needs have similarities. By managing customer knowledge ever better, Ten has become expert at solving similar problems over and over again, getting better at it and more efficient as it does so. Ten's pioneering of 'economies of scale in customer knowledge' could also have farreaching implications for consumer goods industries.

Arnd Huchzermeier arnd.huchzermeier@whu.edu Vallendar, Germany 
Nader Tavassoli presents another perspective on the same question. Traditionally, marketers have focused on who they sold to and what they bought. In doing so, they have tended to miss the why - the 'task' the consumer is trying to address. Focusing on these tasks and goals can lead to powerful insights that break free of me-too conventional marketing.

We have another reminder of the dangers of me-too thinking in our Afterthought where Alan Mitchell reminds us of the pioneering work of Professor Andrew Ehrenberg, who laid the statistical foundations for the study of brands. Many years ago, Ehrenberg challenged the marketing profession with the discovery of 'double jeopardy'. He showed that across markets brands show a common and unchanging pattern of consumer purchases: big brands are bought by more people and more often. It's surprising how many marketing strategies and tactics still try to defy this basic 'law' of brand gravity.

Creating shared value with consumers is most effectively based on collaboration between retailers and suppliers upstream. Upender Subramanian and Jagmohan S. Raju's study of the controversial practice of category captainship shows how it makes good business sense in some circumstances but not in others. As with so many powerful ideas, the real value only begins to flow once we have a clear framework for applicability: knowing when and where it is inappropriate to use it.

Another, more literal, approach to 'shared value' is shared use of core assets such as warehouses. Not long ago, any suggestion that one company should share a warehouse with its competitors would have been dismissed out of hand. But as Rod Franklin and Stefan Spinler show in their article, the efficiency and environmental benefits of this approach certainly need considering.

Another overlooked but important opportunity in improving supply chain performance is who and how the trade credit between suppliers, manufacturers and retailers is best shared. Bigger companies are tempted to squeeze their suppliers and push out the payment terms, but in fact they have better access to credit than smaller suppliers. As Ralf W. Seifert and Daniel Seifert show in their research, these costs in the end get passed on. There are some new win-win opportunities for jointly managing this significant cost in every supply chain.

Finally, we welcome Xavier Hua as the new MD of ECR Europe and wish him well as he redefines the role and purpose of ECR Europe within the new CGF. We look forward to working with him in the future as the industry grapples with the challenges ahead. We would also like to say farewell and a big thank you to Alain Galaski, who throughout his long tenure looking after the finances of ECR always bent over backwards to help us create what he regarded as an important voice for the collaborative agenda for this industry.

The Editorial team:

Daniel T. Jones, Arnd Huchzermeier and Alan Mitchell. 